\title{
Crack Pixels Detection from Inner Side of Drain by Using Variable-sized Directional Filter
}

\author{
Toshiyuki Hatada Non-member (Gifu University) \\ Kunihiro Goto Student Member (Gifu University) \\ Fumihiko Saitoh Member (Gifu University) \\ Takayoshi OOSAKA Non-member (Tokyo Metropolitan Sewer-pipeline Service Co., Ltd.) \\ Shinji NUMAO Member (Nippon Koei Co., Ltd.) \\ Noriyuki HARIMOTO Non-member (Nippon Koei Co., Ltd.)
}

Keywords : crack, line detection, adaptive filter

This paper proposes a method to detect candidate pixels for cracks on an inner side of drain by image processing. Fig. 1 shows an image of an inner side of drain. As a crack is recognized as lines having a thin width, the conception of the proposed method is based on the line detection. The proposed method is comprised of two phases. One is line enhancement process, and another is the process for threshold determination by using features of cracks.

In paper, an adaptive filter that has variable directions and sizes to enhance cracks with arbitrary form is proposed. These two parameters are controlled to be adaptive the form of a crack. Fig. 2 shows a concept of the proposed adaptive filter.

The size of the filter is enlarged from the small size to the pre-decided large size sequentially. In every pixel, the directional filter as shown in Fig. 3 is applied to find the optimal direction of a crack. The direction with the maximum output value of the filter is selected as the direction of the crack. Fig. 4 shows a resultant image generated by the adaptive filter.

The continuous direction is an important feature of a crack. In the proposed method, thresholds to detect pixels on a crack are determined dynamically by using the directional strength in a local

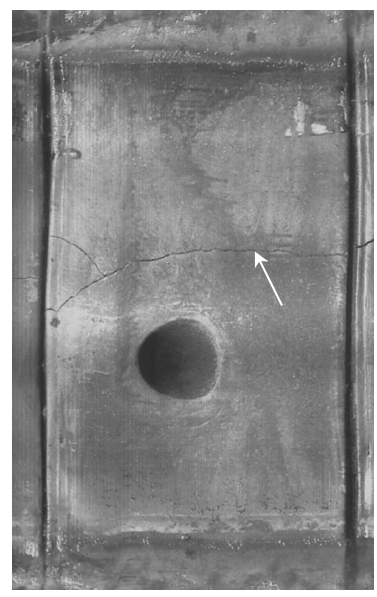

Fig. 1. Image of the inner side of drain

block area. The resultant image by the adaptive filter is divided into multiple block areas and the variance of directions is calculated to determine the threshold to detect candidate pixels for a crack in every block area. Fig. 5 shows the detected candidate pixels for a crack by the above threshold technique.

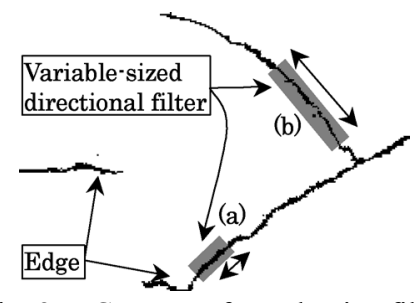

Fig. 2. Concept of an adaptive filter

\begin{tabular}{|c|c|c|}
\hline-2 & 1 & 1 \\
\hline 1 & -2 & 1 \\
\hline 1 & 1 & -2 \\
\hline
\end{tabular}$\quad$\begin{tabular}{|c|c|c|}
\hline 1 & 1 & 1 \\
\hline-2 & -2 & -2 \\
\hline 1 & 1 & 1 \\
\hline
\end{tabular}$\quad$\begin{tabular}{|c|c|c|}
\hline 1 & 1 & -2 \\
\hline 1 & -2 & 1 \\
\hline-2 & 1 & 1 \\
\hline
\end{tabular} \mid \begin{tabular}{|c|c|c|}
\hline 1 & -2 & 1 \\
\hline 1 & -2 & 1 \\
\hline 1 & -2 & 1 \\
\hline
\end{tabular}

Fig. 3. Example of a directional filter

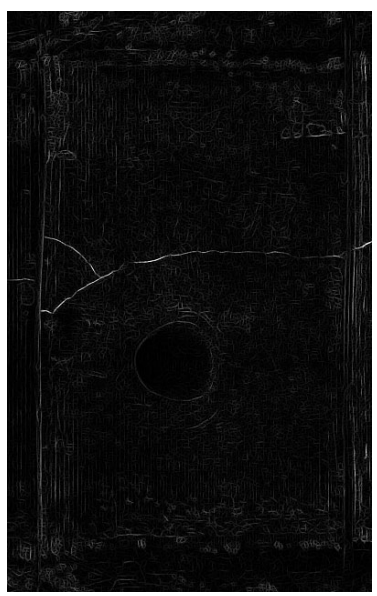

Fig. 4. Result of filter process

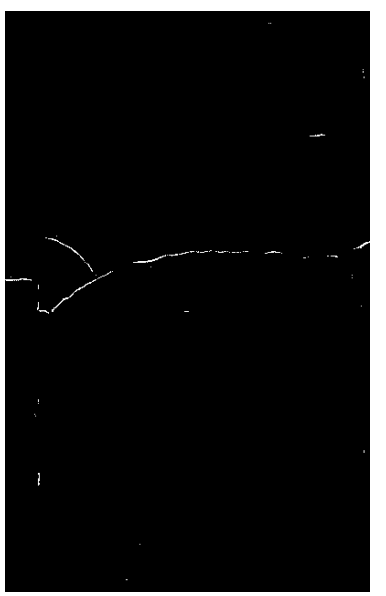

Fig. 5. Experimental result 


\section{方向サイズ可変フィルタを用いた下水道内面ひび割れ候補画素の検出}

$\begin{array}{llll}\text { 非会員 幡田 } & \text { 敏行* } & \text { 学生員 後藤 } & \text { 邦博* } \\ \text { 正 員 斉藤 } & \text { 文彦* } & \text { 非会員 大坂 } & \text { 昂資** } \\ \text { 正 員 沼尾 } & \text { 信二*** } & \text { 非会員 張本 } & \text { 紀行*** }\end{array}$

\section{Crack Pixels Detection from Inner Side of Drain by Using Variable-sized Directional Filter}

Toshiyuki Hatada*, Non-member, Kunihiro Goto*, Student Member, Fumihiko Saitoh*, Member,

Takayoshi Oosaka**, Non־member, Shinji Numao***, Member, Noriyuki Harimoto***, Non-member

This paper proposes a method to detect cracks in the inner side of a drain by using the edge detection techniques. Cracks can be recognized as lines with a thin width. Therefore a method for extracting edges is assumed to be useful to detect cracks. To detect a crack with an arbitrary global form, the variable-sized directional filter is applied. This filter can be set at every pixel with an optimal size and with an optimal direction. After the filter process, the threshold technique that determines a threshold to detect a crack by using its global feature is processed. The experimental results show that the proposed variable-sized directional filter and the threshold technique were effective to detect cracks in the images of inner side of drain.

キーワード : ひび割れ，下水道，線検出フィルタ

Keywords : crack, drain, line detection filter

\section{1. はじめに}

コンクリートによって作られた構造物は頑強であるが， 老朽化や地震等の災害により，ひび割れが生じる。下水道 もコンクリートで建造されたものであり, その維持のため には，定期的な検査が必要となる。目視によって検出され たひび割れを分析し, 診断するシステムは, いくつか提案 されているが(1)(2)，ひび割れの検出精度は，検査者の熟練度 でばらつきが生じることや，検出の再現性が問題となるた め, ひび割れ検出は自動化が望まれている。

コンクリート構造物からのひび割れ検出を自動化したシ ステムとして，レーザーを用いた検出システムが既に実用 化されているが(3)，トラック型のレーザー計測車を用いるた め, 大型のセンシング装置が必要になる。本論文で対象と

\footnotetext{
* 岐阜大学工学部応用情報学科

干501-1193 岐阜県岐阜市柳戸 1-1

Department of Information Science, Faculty of

Engineering, Gifu University

1-1 yanaido, Gifu City, Gifu 501-1193

** 東京都下水道サービス株式会社

干100-8699 東京都千代田区大手町 2-6-2

Tokyo Metropolitan Sewer-pipeline Service CO., LTD.

2-6-2 otetmachi, Chiyoda-ku, Tokyo 100-8699

$* * *$ 日本工営株式会社

干102-0083 東京都千代田区靝町 5-4

Nippon Koei Co., Ltd.

5-4 koujimachi, Tiyoda-ku, Tokyo 102-0083
}

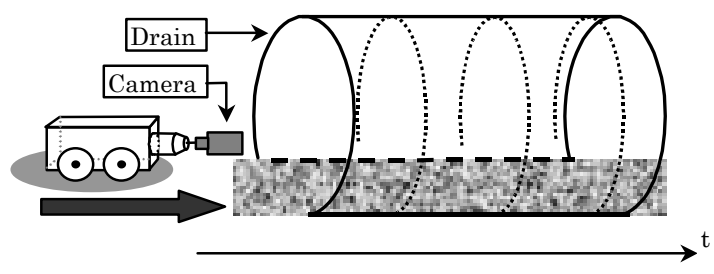

図 1 下水道内面画像の撮影

Fig. 1. Image recording of a drain.

する下水道の場合は, 人間が入ることができない程度の細 い管もあるため，大型のシステムは利用できない。現状の 検査工程では, 単眼カメラによる映像から検査員が目視に よってひび割れを検出している。従って, カメラ映像によ る目視検出を自動化することを最終的な目的とする。

下水道内面画像は, まず, 図 1 に示す様に全方位の可視 光 CCD カメラを装着した走行ロボットによって撮影する。 そして, 動画像内の各フレームに映っている下水道を, 円 周上に切り出し, 展開した各フレーム画像を連結すること で, 図 2 に示す様な静止画像が得られる(4)。従って, 図 2 に示した画像に下水道内面全体が撮影されている。静止画 像より, ひび割れ候補画素を検出する手法として, 画像を ブロック領域に分割し，各ブロックについて Hough 変換 (5)(6)を拡張した GSHT(Gray-scale Hough Transform)を適 
用することで，直線的なひび割れを部分ごとに検出する手 法(7)が提案されているが，GSHT では，全画素に対して投 票処理を行うため, 多くの計算コストを必要とする。

下水道には, 污れや水面の反射等, ひび割れ検出の妨げ となるものが多く，また，ひび割れそのものについても， 濃度值が一定でなく形状も不定である。誤検出を抑えるた めには，下水道内面に発生するひび割れに特化した手法が 必要となる。本論文で提案する手法では，ひび割れの線幅 が比較的細いことより, 線検出を基本とする。線検出手法 として, 零交差法(8)や, Wavelet 変換による多重解像度解析 を用いる手法(9)等が提案されているが, 零交差法では微分值 が変化する 1 画素幅の線が検出されることから，もともと 極めて線幅の狭いひび割れの検出には向いていない。また, ひび割れの方向や線幅が不規則に変化するため, Wavelet 変換による手法では, 多重解像度画像の解析の際に, 基底 関数の設定が困難と考えられる。提案手法では, 線検出フ イルタを適用した後に, 閾值処理を施す流れを取る。ひび 割れの方向や長さの変化に対応するために, 方向, 及びサ イズを適応的に変化させる方向サイズ可変フィルタによっ て, ひび割れの部分ごとの不規則な変化に対応し，その処 理結果を大局的に扱う閾值処理によって，ひび割れ候補画 素と背景領域を識別する。

\section{2. 下水道画像からのひび割れ候補画素検出手法}

ここでは，ひび割れの特徴について述べた後，ひび割れ 候補画素の検出手法について述べる。

〈2·1〉 ひび割れの特徵図 2 に, 本論文で扱う対象 画像例を示す。画像中央の矢印付近に，ひび割れが確認で き，特徴として以下の 4 項目が挙げられる。

（1）周辺部よりも濃度值が低い

(2) 細い線幅である

（3）背景構造物に対して長さがある

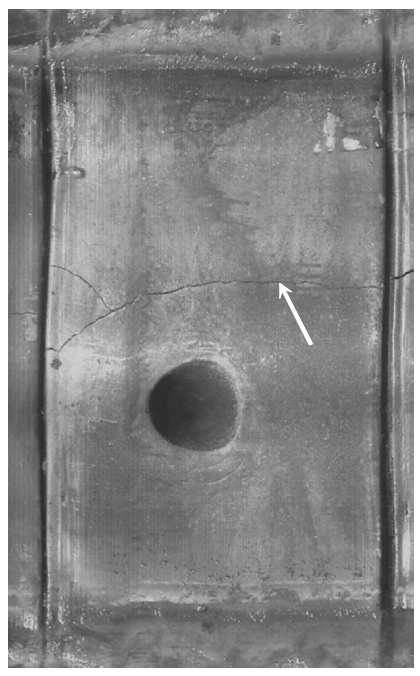

(a) Image1

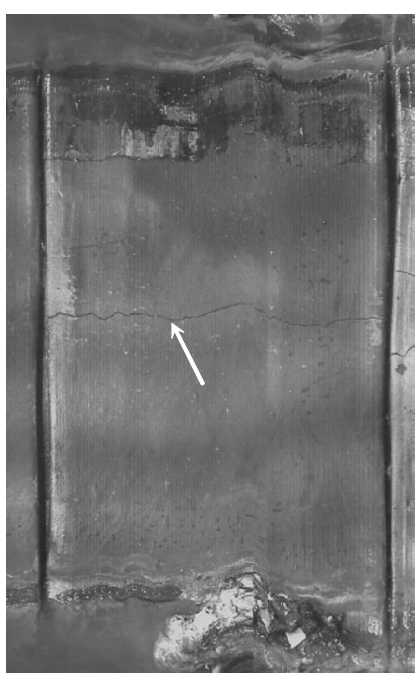

(b) Image2
図 2 下水道内面画像

Fig. 2. Images of drains.
（4）局所的には不定形状だが，大局的には方向性を持つ (1)より，濃度值を閾值とした閾值処理手法が利用できると 考えられる。しかし, 図 2 からも明らかである様に, 背景 構造物にも濃度值が低いものが含まれるため, 濃度值のみ を用いた闇值処理では不十分であることが予想される。

（1）に加え，(2)を併せると，ひび割れは線と見なすことが でき, その検出手法には, 線検出手法を用いることができ ると考えられる。線検出手法では, 線検出フィルタによっ て, 線を構成する画素におけるフィルタ反応值が高くなる ことから, 原画像一直接に濃度值による閾值処理を施す場 合に比べ，誤検出の抑制が期待できる。しかし，ひび割れ を線として捉えるだけでは, 背景構造物のエッジ部分との 識別は困難であり，フィルタ処理と闇值処理のそれぞれに ついて, 特徴(3), (4)を用いる手法が必要となる。

$\langle 2 \cdot 2\rangle$ 従来の線検出フィルタの問題点 広く知られ た線検出フィルタとして, Prewitt フィルタ(10), Sobel フィ ルタ(10)(11)等が挙げられる。これら既存の線検出フィルタは, サイズ $3 \times 3$ 画素の微分フィルタであり, それぞれを $F$ と表 記した場合, 対象画像 $I$ の座標 $(i, j)$ における, フィルタの出 力值 $O(i, j)$ は, 次式で求められる。

$$
O(i, j)=\sum_{u=0}^{2} \sum_{v=0}^{2} I(i+u-1, j+v-1) \cdot F(u, v)
$$

式(1)から出力值 $O(i, j)$ は, 重畳する $3 \times 3$ 画素の局所領域 中の濃度のみに依存し, その外側領域の濃度に影響されな い。よって, 狭い領域範囲で重畳するフィルタでは, $\langle 2 \cdot 1\rangle$ 節で挙げた特徵(3)を利用できず, ひび割れも, 背景構造物 のエッジ部分と同程度に検出される。

方向性を考慮したフィルタとして, 図 3 に示すように, フィルタを取り得る方向分用意し, 画素ごとに方向角度を 変化させる方向可変フィルタが考えられる。図 3 は, サイ ズ $3 \times 3$ 画素の方向可変フィルタの例である。各画素につい て, 図 3 のフィルタ(a)から(d)を, 式(1)の $F$ として対象画 像に適用し, その最大值を記録したフィルタの出力を, 座 標 $(i, j)$ の出力とする。画素ごとに線方向に最適なフィルタが
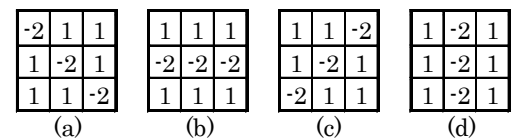

図 3 方向可変フィルタ

Fig. 3. Directional filter.

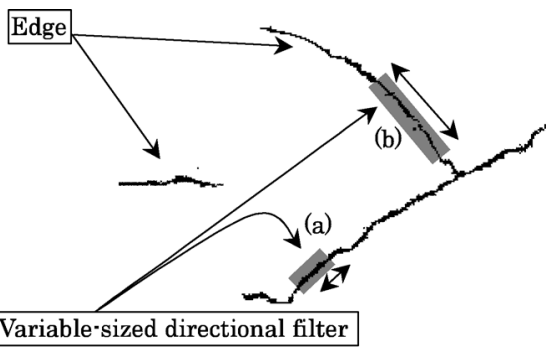

図 4 方向サイズ可変フィルタの概念

Fig. 4. Concept of variable-sized directional filter. 
選択されるが, フィルタのサイズは一定なため, 特徴(3)を 十分に利用することはできない。

\section{〈2·3〉 方向サイズ可変フィルタ 以上に述べた点か} ら，〈2・1〉節で挙げた特徴を全て利用するには，ひび割れ の形状に動的に適応寸るフィルタが有効と考えられる。〈2. 2〉節で述べた方向可変フィルタは，画素ごとに方向を変化 させることにより，特徴(1)，(2)，(4)を利用できるが，フィ ルタの重畳可能なサイズが不明であるために, 特徴(3)に対 応できない。そこで, 本論文では方向だけでなく, サイズ も画素ごとに変化させることで特徴(3)に対応する手法を提 案する。このフィルタの概念を図 4 に示す。灰色の長方形 はフィルタを，その右隣の矢印がフィルタの方向を表す。 図 4(a)と(b)について，フィルタの方向が，それぞれのひび 割れ部分に合わせて変化し，またサイズについては，（b) では(a)よりも，ひび割れの直線形状部に伴って長くなって いる。方向とサイズの 2 つのパラメータを適応的に変化さ せるので，この手法を方向サイズ可変フィルタと呼ぶもの とし, 次章で処理の具体的な内容について述べる。

$\langle 2 \cdot 4\rangle$ フィルタ出力の統合による閾值処理 方向サ イズ可変フィルタは, フィルタ反応值の他に, 動的に決定 された方向, 及び, サイズの各パラメータ值も出力する。 フィルタサイズを大きくしても, フィルタ係数がひび割れ に適合しなければ，反応值の向上には効果が表れず，逆に 誤検出を招く可能性が考えられるため, その適用サイズに は限界がある。特徴(4)より, 方向性は, ひび割れの大局的 な特徵であることから, 画素ごとに得られた方向パラメー 夕值は，ある程度の領域ごとに扱うことで, 背景構造物の 領域との差が見出せられると考えられる。提案手法では, 方向サイズ可変フィルタの適用後画像をブロック領域に分 割し，それぞれのブロックについて，フィルタの出力を統 合した結果を用いることで, フィルタ適用後画像に対する 濃度の閾值を決定する。そして，画素ごとに設定した閾值 によって，ひび割れ候補画素を検出する。詳しい処理の流 れについては，4章で述べる。

\section{3. 方向サイズ可変フィルタ}

ここでは, 方向サイズ可変フィルタの処理手順について 述べる。フィルタの方向とサイズを決定する最も単純な方

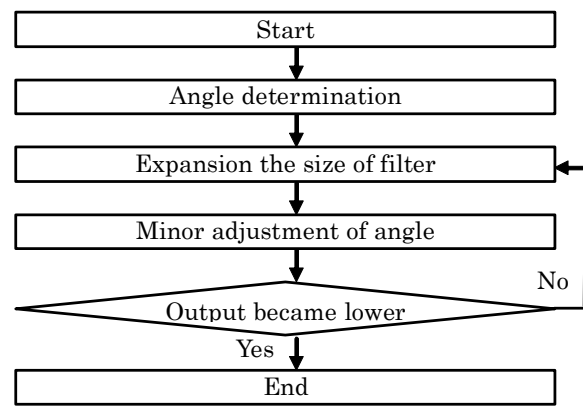

図 5 方向・サイズ可変フィルタのフローチャート

Fig. 5. Flow-chart of variable-sized directional filter.
法として, 全ての組み合わせについて試すことが挙げられ る。しかし, 全方向について, あらゆるサイズのフィルタ をテストすることは, 計算コストの点から望ましくない。

方向サイズ可変フィルタでは, 図 5 に示すように，まず，

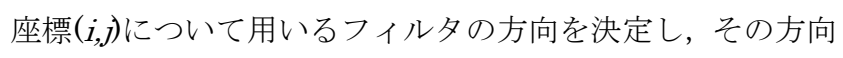
についてフィルタサイズを徐々に伸長させ, 適切なサイズ を決定する。フィルタサイズの伸長とは，ひび割れの方向 性により, 角度決定で得られた角度 $\phi=\theta(i, j)$ に延長した先 に, ひび割れ画素が連続している可能性が高く, 逆にこの 角度に対して垂直な方向については，ノイズとなる背景領 域である可能性が高いことに着目し, 単純に角度 $\phi$ の線を 検出するよう, サイズを拡大寸るのではなく, 角度 $\phi に つ$ いて両端に 1 ずつ, フィルタの長さとしては 2 ずつ伸長さ せる処理である。これにより，サイズは $10 \times 10$ から，(10+2） $\times 1_{0},\left(1_{0}+4\right) \times 1_{0}, \ldots,\left(1_{0}+2 \times k\right) \times 1_{0}$ という具合に変化し, 初 期サイズを除いて形状は長方形となる。図 6 に, サイズを 3 $\times 3$ 画素から $5 \times 3$ 画素, $7 \times 3$ 画素へと伸長する例を示す。

方向パラメータを $d$ とし, フィルタサイズは $I \times 10$ 画素の 様に記述できるので, サイズのパラメータを 1 と表記するも のとして，以下に具体的な処理手順を述べる。

〈3・1〉 フィルタサイズと方向分解能の関係 まず, フィルタのサイズと, 方向分解能の関係について述べる。 用いるフィルタは, 方向可変フィルタと同様に, 直線状に 負の係数, その周辺に正の係数を設定する。図 7 中の番号 を $n$ とすると, 各 $n$ から, 中央座標へ向かって引ける直線 の数は, 一辺が 1 の場合 $(1+(1-2))$ となり, この数がフィルタ の分解能に対応する。よって, サイズ $I \times I$ 画素のフィルタ における方向分解能 $D($ ゆ，次式で表される。

$$
D(l)=l+(l-2)
$$

フィルタを伸長した場合でも, 分解能は, サイズ $I \times 1$ 画素 の正方領域内で考えるものとし, 式(2)で計算される。

$x$ 軸が右向き方向に正, $y$ 軸が下向き方向に正となる座標 系を用いた際の, フィルタ番号 $n$ に対応する実際の角度は,

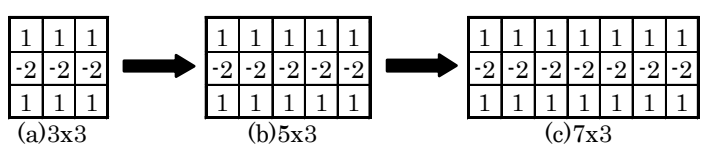

図 6 フィルタサイズの伸長過程

Fig. 6. Expansion process of filter size.

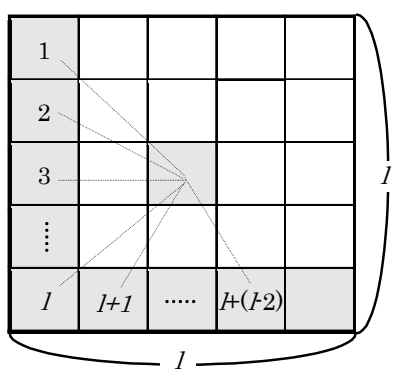

図 7 フィルタサイズ

Fig. 7. Filter size. 
$l$ を用いて, 次式の関数 $R(1, n)$ で表される。

$$
R(l, n)=\left(\frac{1}{4}-\frac{n}{D(l)}\right) \cdot \pi
$$

〈3・2〉角度の決定用いるフィルタの角度は, 線の 方向に沿う角度, 即ち, 反応值が最大值をとる角度となる。 サイズ $1 \times 1$ 画素，方向 $R(1, n)$ のフィルタを $F_{l, R(l, n)}$ と表記す ると, 座標 $(i, j)$ における反応值 $O_{l, R(l, n)}(i, j)$ は, 式( 1 )を一般化 した，次式によって計算される。

$$
\begin{aligned}
& O_{l, R(l, n)}(i, j) \\
& \quad=\sum_{u=0}^{l-1} \sum_{v=0}^{l-1} I\left(i+u-\left\lfloor\frac{l}{2}\right\rfloor, j+v-\left\lfloor\frac{l}{2}\right\rfloor\right) \cdot F_{l, R(l, n)}(u, v)
\end{aligned}
$$

座標 $(i, j)$ の画素において, 反応值が最大となるフィルタの 角度 $\theta(i, j)$ は, 次式によって表される。

$$
\begin{aligned}
& \theta(i, j)=R\left(l, n_{\max }\right) \\
& n_{\max }=\max _{n}\left(O_{l, R(l, n)}(i, j)\right) \quad(n=0,1, \ldots, D(l)-1)
\end{aligned}
$$

〈3.3〉 フィルタの伸長と角度の微調整次に, 得ら れたフィルタの角度について, サイズを $1_{0} \times 1_{0}$ から徐々に伸 長する。フィルタは直線状の線画素を検出するものである から, あるサイズパラメータIについて, 伸長後のサイズパ ラメータを皇し, フィルタの角度を $\phi$ とすると, 伸長先の 領域に線が連結している場合, 次の関係式が成立し, フィ ルタ伸長が適切であるかを判断する基準となる。

$$
O_{l, \phi}(i, j)>O_{l, \phi}(i, j)
$$

式(6)の条件は, 背景構造物の中に, 極端に長い直線状構 造物が含まれている場合も満たされるため, 誤検出を防ぐ ために, フィルタの最大サイズ $L$ を決めておく。また, 式(2) より, 伸長前のフィルタの方が, 伸長後よりも方向分解能 が小さいため, 一方向分のフィルタで比べた場合, 伸長後 よりも広い角度についての情報を含んでいると考えられ る。そこで角度 $\phi$ について, 分解能 $D\left(l^{\prime}\right)$ で前後の角度 $(\phi-$ $\phi),(\phi+\phi)$ それぞれを持つフィルタとの反応值を求め, そ れらとの平均を, 式 $(7)$ の $O_{l^{\prime}, \phi}(i, j)$ の換わりに用いる。これ らより, サイズの伸長の継続を決定する条件式は, 式(6) を改め, 次式となる。

$$
\left.\begin{array}{l}
\frac{O_{l^{\prime},\left(\phi-\phi^{\prime}\right)}(i, j)+O_{l^{\prime}, \phi}(i, j)+O_{l^{\prime},\left(\phi+\phi^{\prime}\right)}(i, j)}{3}>O_{l, \phi}(i, j) \\
l^{\prime} \leq L
\end{array}\right\} \cdots
$$

式(7)が成り立つ間，Iを $l^{\prime}$ で更新し，フィルタの伸長を

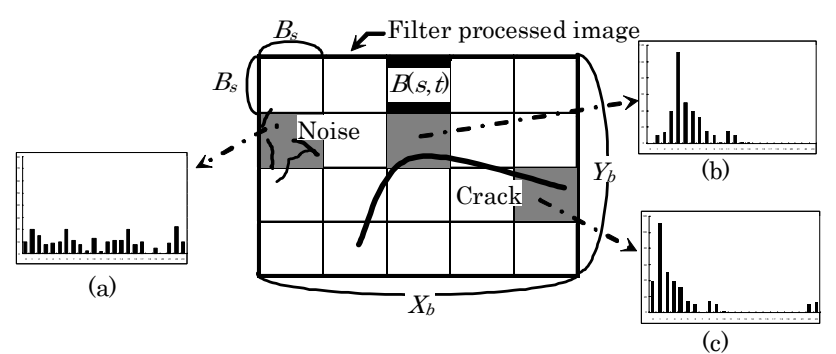

図 8 フィルタ処理画像のブロック分割

Fig. 8. Block separation of filter processed image.
続ける。伸長の際には, $O_{\left.I^{\prime},{ }_{\phi}{ }^{-}{ }_{\phi}\right)}(i, j), O_{I^{\prime}{ }_{\phi}}(i, j), O_{\left.l^{\prime},{ }_{\phi}{ }^{+}{ }_{\phi}\right)}(i, j)$ の中で最大值を取った角度を用いて $\phi$ を更新し, 伸長で角 度分解能が増したことに対する角度の微調整を行う。最終 的に得られたサイズ $1 \times 10$ 画素のフィルタについて, その時 の $\phi$ で $\theta(i, j)$ を更新し, $O_{l^{\prime}, \phi}(i, j)$ の值を座標 $(i, j)$ におけるフィ ルタ反応值とする。全画素に対して得られた $O_{I^{\prime}{ }_{\phi}}(i, j)$ は, 線 検出フィルタの適用後画像であり, 表記を $I_{F}$ と改める。

\section{4. フィルタ出カの統合処理を用いた閾值処理}

方向サイズ可変フィルタを対象画像 $I$ に適用して得られ た濃淡画像 $I_{F}$ から, ひび割れを白, 背景を黒とした二值画 像を求めるため, $I_{F}(i, j)$ と $\theta(i, j)$ を統合した結果より濃度閾值 を決定し， $I_{F}$ に二值化を施す。〈2・1 $\rangle$ 節で挙げた特徵(4)を 利用するため, フィルタの出力画像 $I_{F}$ を図 8 に示すように, $B_{s} \times B_{s}$ 画素の方形領域によって, $X_{b} \times Y_{b}$ 個のブロック領域 $B(s, t)\left(0 \leqq s<X_{b}, 0 \leqq t<Y_{b}\right)$ に分割し, 各ブロック $B(s, t)$ ごと にフィルタの出力 $I_{F}(i, j)$ と $\theta(i, j)$ を扱う統合処理を行う。こ こで統合処理とは，ある画素が，ひび割れ画素であるかど うかをブロックという大局的な領域内の情報を用いて識別 する処理である。即ち, ブロック内における各々の画素を, ブロックという大局的な領域内のフィルタ反応值や, 方向 の連続性を評価することで，ひび割れ候補画素かどうかを 識別する閾值をブロック単位に決定する処理である。 $B(s, t)$ ごとには, 以下の特徴量を計算する。図 8 中のヒストグラ ムは, 横軸に角度, 縦軸をその頻度とした角度ヒストグラ ム $h(s, t)$ であり, 角度の分解能は $D(L)$ である。大きいフィ ルタ反応值を重視するため, 頻度は $I_{F}(i, j)$ を重みとする。図 8(b), (c)に示すひび割れ領域では, 図 8(a)に示すノイズ領域 に対し, 角度ヒストグラムのばらつきが小さくなる。また, ノイズ領域はエッジが局所的に集中するため, 濃度值の合 計值が大きくなる傾向にある。これら特徵から， $B(s, t)$ ごと の角度分散 $V(s, t)$ 及び, 反応值の合計值 $B_{\mathrm{sum}}(s, t)$ をパラメー タとして, 濃度の閾值決定を行う。閾值決定では, $B(s, t)$ ご とに得たヒストグラムで角度分散を計算する手法と, $B(s, t)$ と, その周辺ブロック $B\left(s^{\prime}, t^{\prime}\right)$ の情報を併せて角度分散を求 める手法の 2 種類を $\langle 4 \cdot 4\rangle$ 節と $\langle 4 \cdot 5\rangle$ 節で検討する。

〈4·1〉 フィルタの角度の周期性 方向サイズ可変フ イルタでは, フィルタ係数を直線状に設定するため, 角度 $\alpha$ のフィルタと, 角度 $\alpha \pm k \pi(k=\ldots,-2,-1,0,1,2, \ldots)$ のフィル 夕は等価である。よって, フィルタの角度は周期性を持つ。 〈4·2〉重み付き角度ヒストグラム 角度ヒストグラ ム $h(s, t)$ を求める際には, ブロック内の座標 $(i b, j b)$ にいて, 角度 $\theta\left(i_{b}, j_{b}\right)$ から次式を満たすインデックス值 $i_{h}$ を求め, $h(s, t)\left[i_{h}\right]$ 一 $I_{F}\left(i_{b}, j_{b}\right)$ を重みとして累積する。

$$
R\left(i_{h}, L\right) \leq \theta\left(i_{b}, j_{b}\right)<R\left(i_{h}+1, L\right)
$$

但し， $I_{F}\left(i_{b}, j_{b}\right)$ がブロック内での平均值より小さい場合は, 有効性が低いものとして, $h(s, t)$ に対する操作は行わない。 また, 対象画像には, 動画像から静止画像を生成した際に 生じた結合部に, 縦方向の線上ノイズが含まれることから, $B_{s}$ に対して $80 \%$ 以上の長さを持つ縦方向の直線はノイズと 
見なし，この場合も $h(s, t)$ に対する操作を行わない。

このようにして求めた $h(s, t)$ にいて, 高い濃度值の画素 から得られたピークを重視するため, 重みを 1 としたもう 一つのヒストグラム $h_{1}(s, t)$ も求め, 次式によってヒストグ ラム $h(s, t)$ の全インデックス值について，1画素あたりの重 みを掛け合わせてから正規化したヒストグラム $h^{\prime}(s, t)$ を求 め, 以後の処理で用いる。

$$
\left.\begin{array}{l}
h^{\prime}(s, t)\left[i_{h}\right]=\frac{h_{\mathrm{temp}}(s, t)\left[i_{h}\right]}{\sum_{n=0}^{D(L)-1} h_{\mathrm{temp}}(s, t)[n]} \\
h_{\mathrm{temp}}(s, t)\left[i_{h}\right]=h(s, t)\left[i_{h}\right] \cdot \frac{h(s, t)\left[i_{h}\right]}{h_{1}(s, t)\left[i_{h}\right]}
\end{array}\right\}
$$

〈4·3〉 フィルタの角度分散 $\quad h(s, t)$ から分散 $V(s, t)$ を 求める計算式は, $B(s, t)$ での平均角度 $\phi m(s, t)$ を用いて, 次式 で表される。

$$
V(s, t)=\sum_{n=0}^{D(L)-1} S\left(R(L, n), \phi_{m}(s, t)\right)^{2} \cdot h^{\prime}(s, t)[\mathrm{n}]
$$

但し, 関数 $S(\alpha, \beta)$ は, フィルタ角度の周期性を考慮し, 二 つの角度 $\alpha, \beta$ の角度差を $\pi / 2$ 以内で求める関数である。

$$
S(\alpha, \beta)= \begin{cases}\pi-|\alpha-\beta| & \left(\text { if }|\alpha-\beta|>\frac{\pi}{2}\right. \text { ) } \\ |\alpha-\beta| & \text { (otherwise) }\end{cases}
$$

また，平均角度 $\phi_{m}(s, t)$ は，図 9 の場合のように，ピークが 両端にあるヒストグラムの場合は, 単純計算では平均の意 味合いより, ヒストグラム中央の角度 $R(L, D(L) / 2)$ となるが, 実際には $R(L, 0)$ か, $R(L, D(L)-1)$ のいずれかとなる。そこで, フィルタの周期性を利用し，ピークがヒストグラム中央と なるよう，ヒストグラムをシフトして平均角度 $\phi_{m}(s, t)$ を求 め，その後にシフトした分の角度を戻す。

$\langle 4 \cdot 4\rangle$ 閾值決定法 前節で求めた角度分散值 $V(s, t)$ に加えて，章の始めで述べたように，ノイズの局所性を用 いるため, $B(s, t)$ での濃度值の合計值 $B_{\text {sum }}(s, t)$ の值も閾值決 定のパラメータとし，それぞれの最大值に対する割合を用 いた次式で， $B(s, t)$ ごとの閾值 $T(s, t)$ を決定する。

$$
T(s, t)=255 \cdot \frac{V(s, t)}{(\pi / 2)^{2}} \cdot \frac{B_{\text {sum }}(s, t)}{255 \cdot B_{s}^{2}} \cdot c
$$

$c$ は対象画像に応じて設定する定数であり, 壁面の濃度やコ ントラストといった要素で決定される。 $T(s, t)$ のりりる範 囲[0,255]で求め, これによってブロック間の䦨值の差を大 きくとるために, $c$ を加算ではなく乗算とした。ここで $T(s, t)$ が 255 を超えた場合は，255 へと抑える。T $(s, t)$ は，ブロッ クの境界では不連続となるため, $T(s, t)$ をブロックの中心に

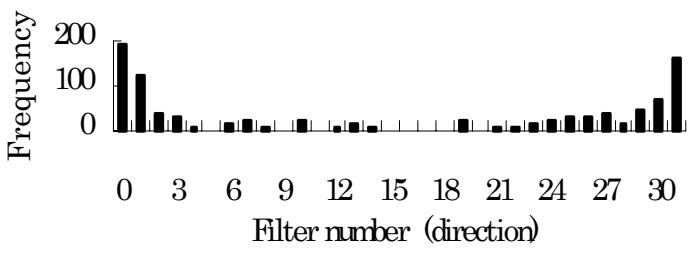

図 9 角度ヒストグラム例

Fig. 9. Example of direction histogram.
おける閾值とし，周辺座標については，隣接ブロックの值 を線形補間をした值を閾值とする。この処理を, 画像 $I_{F}$ 上 の全ての座標について行い, 二值の出力画像 $I_{T}$ を得る。

〈4·5〉周辺ブロックの情報を用いた閾值決定法 ヒ ストグラムのピークは, ひび割れ領域で鋭く, ノイズ領域 では不明瞭となるので, $h^{\prime}(s, t)$ に周辺ブロックのヒストグラ ム $h^{\prime}\left(s^{\prime}, t^{\prime}\right)$ を $h^{\prime}(s, t)$ とピークが揃うようにシフトしてから累 積し, 正規化したヒストグラム $h_{a}^{\prime}(s, t)$ のピークは, ひび割 れ領域ではより鋭く，ノイズ領域ではより不明瞭になると 考えられる。そこで累積する際は, $h^{\prime}(s, t)$ 自体の情報を重視 し, 次式で求められる重み $W$ を $h^{\prime}\left(s^{\prime}, t^{\prime}\right)$ に掛け, $h^{\prime}(s, t)$ 自体 には $W_{s}$ を掛ける。累積先の対象は, $B(s, t)$ での $I_{F}$ の平均值 $B_{\text {mean }}(s, t)$ を距離とした範囲内のブロックとし, 特徵量をよ り大局的に扱い，ひび割れとの差を見出すことを図る。

$$
\begin{aligned}
& W\left(s^{\prime}, t^{\prime}, s, t\right)=\left\{\begin{array}{lr}
0 \quad & \left(\text { if } s^{\prime}=s \text { and } t^{\prime}=t\right) \\
\frac{\left|\cos \left(\phi_{m}(s, t)-\tan ^{-1} \frac{t^{\prime}-t}{s^{\prime}-s}\right)\right|}{\sqrt{\left(s^{\prime}-s\right)^{2}+\left(t^{\prime}-t\right)^{2}}} & \text { (otherwise) }
\end{array}\right. \\
& W_{s}(s, t)=\sum_{u=-B_{\text {mean }}(s, t)}^{B_{\text {manu }}(s, t)-1} \sum_{v=-B_{\text {mean }}(s, t)}^{B_{\text {manu }}(s, t)-1} W(u, v, s, t)
\end{aligned}
$$

式(10)の $h^{\prime}(s, t)$ を $h_{a}^{\prime}(s, t)$ と置き換えることで $V_{a}(s, t)$ を求 め, 式(12)の $V_{s, t}$ を $V_{a}(s, t)$ と置き換えて得た $T_{a}(s, t)$ を用い て $\langle 4 \cdot 4\rangle$ と同様に閾值処理を行い, 出力画像 $I_{T}$ を得る。 $\langle 4 \cdot$

4〉で述べた閾值決定法との比較は，次章にて述べる。

\section{5. 評価実験}

以上に述べた提案手法を実際の下水道内面画像に適用し た結果について述べる。

〈5・1〉実験条件実験に用いる対象画像は, 眓 2 に 示す解像度が $800(\mathrm{~W}) \times 1280(\mathrm{H})$ の, 濃淡レベルが 8 ビット の画像 Image1, Image2 である。それぞれの画像について, 予め目視により, ひび割れ画素を白(1), 背景画素を黒(0)と してトレースした二值画像 $I_{c}(i, j)$ を用意し, 評価基準として 用いる。方向サイズ可変フィルタにおける, サイズパラメ 一タ $1_{0}$ 及び $L$ は, 細かなエッジや, 非ひび割れの直線構造 物の影響を避けられる值として $l_{0}=7, L=17$ とし, フィルタ 係数は, 実験で用いたひび割れ画像の全域について得られ た平均的な濃度プロファイルから図 10 に示した值に設定し た。尚, 図 10 は $=7, n=3$ のフィルタ $F_{7, R(7,3)}$ の場合である。 10 を小さくすると, 細かい線に強く作用し, 逆に大きくする

\begin{tabular}{|c|c|c|c|c|c|c|}
\hline 2.5 & 2.5 & 2.5 & 2.5 & 2.5 & 2.5 & 2.5 \\
\hline 2.0 & 2.0 & 2.0 & 2.0 & 2.0 & 2.0 & 2.0 \\
\hline-1.0 & -1.0 & -1.0 & -1.0 & -1.0 & -1.0 & -1.0 \\
\hline-7.0 & -7.0 & -7.0 & -7.0 & -7.0 & -7.0 & -7.0 \\
\hline-1.0 & -1.0 & -1.0 & -1.0 & -1.0 & -1.0 & -1.0 \\
\hline 2.0 & 2.0 & 2.0 & 2.0 & 2.0 & 2.0 & 2.0 \\
\hline 2.5 & 2.5 & 2.5 & 2.5 & 2.5 & 2.5 & 2.5 \\
\hline
\end{tabular}

図 10 フィルタ係数例

Fig. 10. Example of coefficients of the variable-sized directional filter. 
表 1 フィルタ反応值の結果比較

Table 1. Comparison of filter responded values.

\begin{tabular}{c|c|c|c}
\hline Image Filter & Prewitt & DF & VSDF \\
\hline Image1 & 3.06 & 3.43 & 7.60 \\
\hline Image2 & 2.54 & 3.04 & 5.52 \\
\hline
\end{tabular}

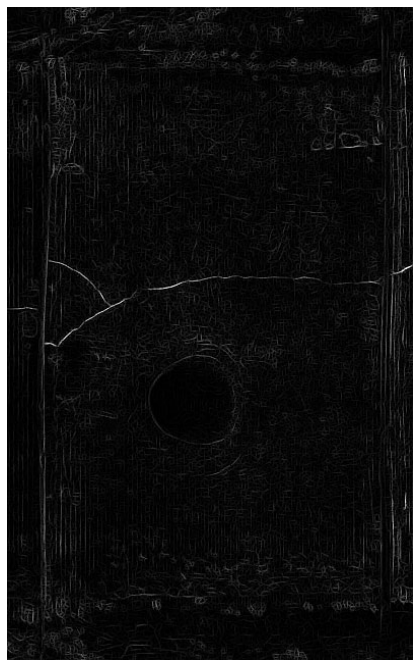

(a)Image1

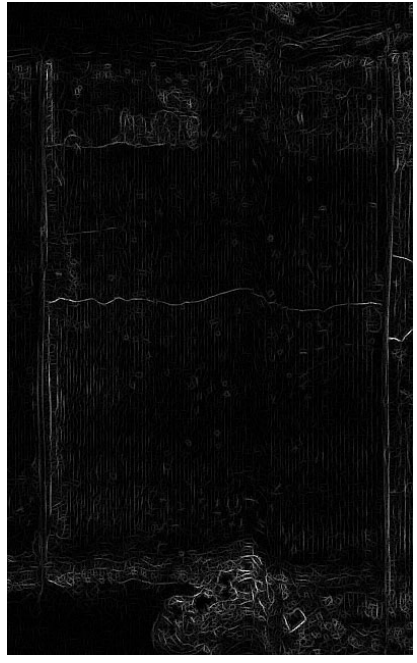

(b)Image2
図 11 フィルタ出力画像

Fig. 11. Output images by variable-sized directional filter.

と, 長い線に作用する。1oが小さいと, どの構造物に対して も, フィルタの出力が大きくなり, フィルタの伸長方向が, ひび割れに対して正しく決定されない恐れがある。 $L$ 小さ くすると，細い線のみに作用し，大きくすると，長い線ま で検出される可能性がある。今回は，10を 3 から 31 まで,

$L$ を， 7 から 49 までの範囲で実験を行ったが，点状の構造 物ではなく，方向性をもった構造物に対して反応值が高く なる点で, $I_{0}=7, L=17$ の場合に最も良好な結果が得られた。 閾值処理のパラメータは, ブロックサイズ $B_{S}$ を, ひび割れ, 及び局所的なコントラストの高い背景構造物を捉えられる サイズとして $B_{S}=32$ と決定し, $c$ の值は, 経験的に $c=35$ と した。これらのパラメータは, Image1, Image2 共に共通 の值とする。

〈5·2〉 フィルタ処理の評価 Image1, Image2 を対 象画像 $I$ とし, 方向サイズ可変フィルタと, 比較対象として, $\langle 2 \cdot 2\rangle$ 節で述べた Prewitt フィルタで得られる出力画像 $I_{F}$ を計算し, 分子にひび割れ画素, 分母に背景画素それぞれ の $I_{F}(i, j)$ の合計值とした值 $E_{F}$ を次式で求め評価值とする。

$$
E_{F}=\frac{\sum_{i=0}^{W-1} \sum_{j=0}^{H-1} I_{F}(i, j) \cdot I_{c}(i, j)}{\sum_{i=0}^{W-1} \sum_{j=0}^{H-1} I_{F}(i, j) \cdot\left(1-I_{c}(i, j)\right)}
$$

以下，方向のみ可変フィルタを DF(Directional Filter), 方向サイズ可変フィルタを VSDF(Variable-sized Directional Filter)と表記し，フィルタそれぞれについて求

\section{表 2 識別率結果比較}

Table 2. Comparison of discernment rates.

\begin{tabular}{c|c|c|c|c}
\hline \hline Image Method & $\mathrm{MT}(I)$ & $\mathrm{MT}\left(I_{F}\right)$ & $\mathrm{PT} 1$ & $\mathrm{PT} 2$ \\
\hline Image1 & 86.01 & 99.19 & 99.49 & 99.64 \\
\hline Image2 & 72.54 & 97.90 & 99.38 & 99.63 \\
\hline
\end{tabular}

めたフィルタ反応值比 $E_{F}$ を評価值として, 対象画像ごとに 表 1 に示す。定量的には, Prewittフィルタに対して, DF は良好な結果值となり，方向性を考慮した成果が表れてい ると考えられる。VSDFでは, 更に良好な結果となり, DF に対して, Image 1 では 2.2 倍, Image 2 について 1.8 倍 の向上が見られた。表 1 に示したフィルタ反応值は, 背景 構造物とひび割れを正しく識別しているほど高くなる。上 記の結果から，VSDF はサイズを可変にした効果が見られ， $\mathrm{DF}$ と比較しても, ひび割れ画素の検出に，より適したフィ ルタであると考えられる。VSDF を施した出力画像を図 11 に示す。Image1 及び Image2 共に, ひび割れに対しての反 応值が高いことが確認できるが, Image 2 においては, 画像 下部のノイズに高い反応值を示していることが確認され た。この部分の影響により, 表 1 における評価值が, Image 1 よりも Image2 の場合に低くなったと考えられる。

$\langle 5 \cdot 3\rangle$ 閾值処理についての評価比較閾值処理の出 力画像 $I_{T}$ は, ひび割れ候補画素検出としての出力であり, その位置精度について, ある程度の誤差が許容される。こ こでは, 真のひび割れ画素について，8近傍の範囲内までを 許容する。ひび割れ検出では, 真のひび割れ画素を検出す ることが重要であるが, 一方で, 非ひび割れ領域について は, ひび割れ画素として誤検出される画素数は少ない方が 良く, どちらの要素もひび割れ検出の出力としては重要で ある。ここでは, ひび割れの画素の検出漏れと, 背景に発 生する誤検出の双方を評価するために, 真のひび割れ画素 の 8 近傍領域に検出された画素数をひび識別画素数 $E_{T C}$, 背 景を背景として正しく識別した画素数を背景識別画素数 $E_{T B}$ とし，次式により識別率 $E_{T}\left(0 \leqq E_{T} \leqq 100\right)$ を計算する。 ひび割れ画素を検出し, かつノイズ画素を背景から検出し なければ, $E_{T C}$ と $E_{T B}$ が共に大きくなり, 全体の評価值 $E_{T}$ が大きくなる。逆に，ひび割れ画素が検出されない場合や ノイズが検出される場合， $E_{T}$ は小さくなる。

$$
E_{T}=\frac{E_{T C}+E_{T B}}{W \cdot H} \cdot 100
$$

評価值 $E_{T}$ は，全画素数に対して，ひび割れをひび割れ， 背景を背景と正識別した画素数の割合を表している。比較 対象として, 目視で最適な閾值決定をする手法 MT(Manual Thresholding method)を挙げる。対象画像 $I$ に直接 MT を 用いる場合を $\operatorname{MT}(I)$, フィルタ出力画像 $I_{F}$ に対して用いる 場合を $\mathrm{MT}\left(I_{F}\right)$ と表記するものとする。また, フィルタ出力 画像 $I_{F}$ に対して用いる, $\langle 4 \cdot 4\rangle$ 節で述べた閾值処理を PT1(Proposed Thresholding 1)，〈4.5〉節で述べた閾值処 理をPT2(Proposed Thresholding 2) と表記し, $E_{t}$ を, MT(I), $\operatorname{MT}\left(I_{F}\right), \mathrm{PT} 1, \mathrm{PT} 2$ それぞれについて計算した結果を表 2 に示 


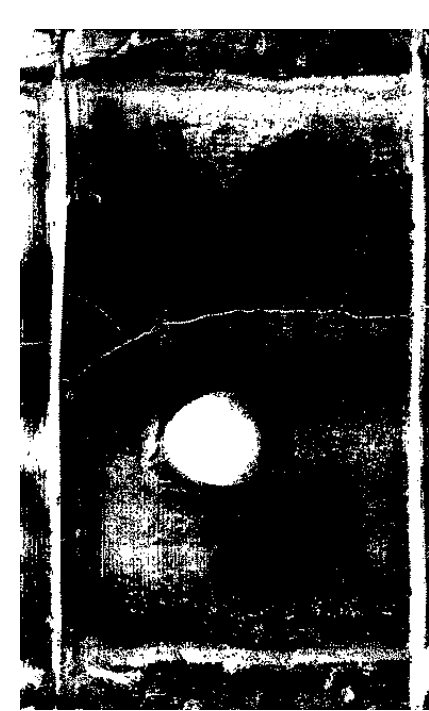

(a) $\operatorname{MT}(I)$

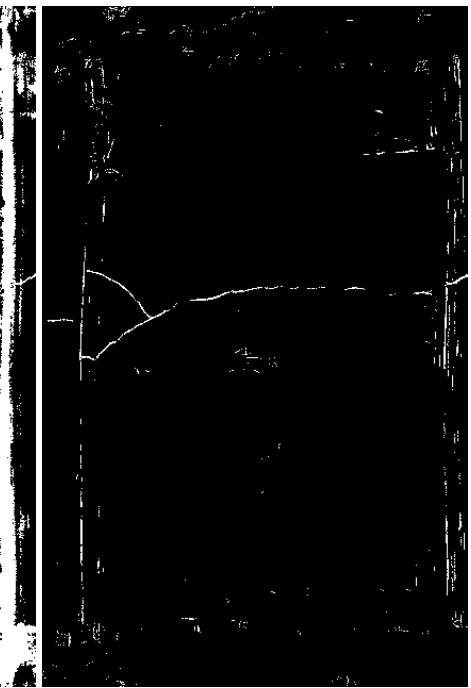

(b) $\mathrm{MT}\left(I_{F}\right)$

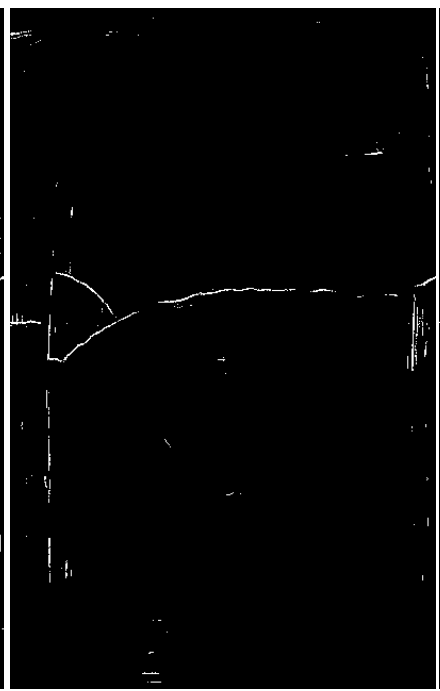

(c) PT1

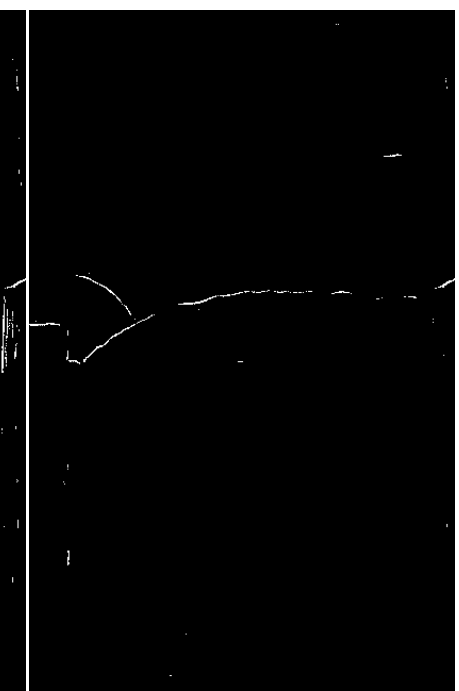

(d) PT2

図 12 ひび割れ検出結果(Image1)

Fig. 12. Detected crack (Image1).

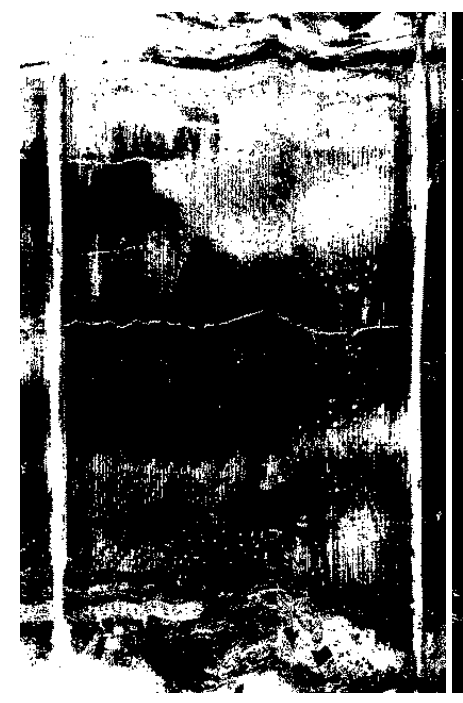

(a) $\mathrm{MT}(I)$

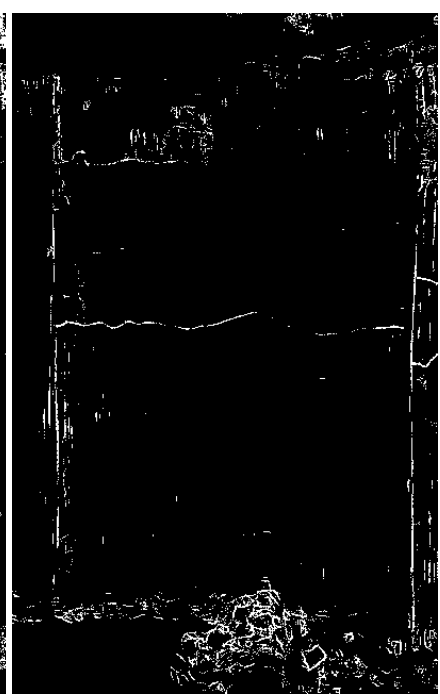

(b) $\operatorname{MT}\left(I_{F}\right)$

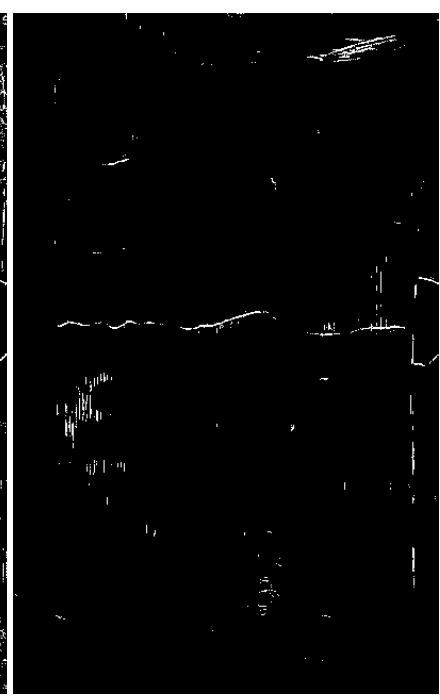

(c) PT1

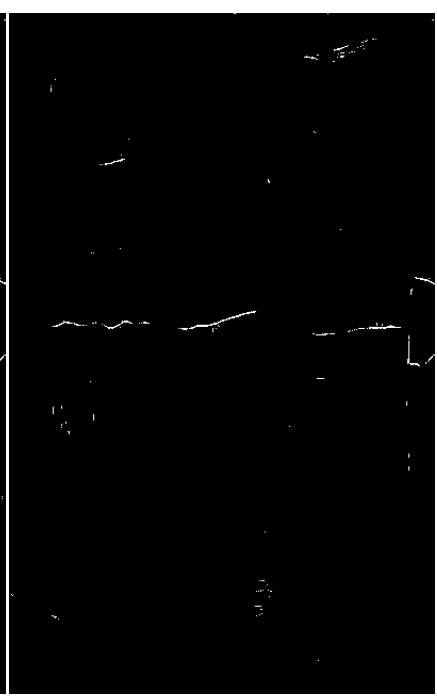

(d) PT2

図 13 ひび割れ検出結果(Image2)

Fig. 13. Detected crack (Image2).

し, 出力画像 $I_{T}$ を図 12 , 図 13 に示寸。 $\mathrm{MT}(I)$ で用いた閾值 は, Image1 について 167, Image2 について $172, \operatorname{MT}\left(I_{F}\right)$ では, Image1について 63, Image2 について 53 とした。

MT(D)定量的に最も悪く, 視覚的にも, ひび割れと背景 とが混在してしまっている。他の手法については, $\mathrm{MT}\left(I_{F}\right)$, PT1, PT2 の順に, 定量的は僅かながら向上し, 視覚的に は,はっきりとした向上が認められる。

$\operatorname{MT}\left(I_{F}\right)$ は目視で閾値を決定したものの，画像全体に一定 の閾值を用いるため, フィルタ処理で高い反応值を示した 背景構造物が検出されている。 PT1 では, ブロックごとの 統合処理によって閾値を決定することで，ノイズを $\operatorname{MT}\left(I_{F}\right)$ よりも抑えられたと考えられる。更に，PT2 では，PT1で 局所的に誤検出される条件を満たしていたブロックが, 周 辺ブロックの情報を利用することで検出条件を満たさなく
なり，ノイズを減少させる効果が得られたと考えられる。 しかし, PT1, PT2 いずれについても, ブロックのサイズ よりも小さい領域, 即ち $32 \times 32$ 画素よりも狭い範囲で, ひ び割れの方向が特に複雑に変化している部位や，ひび割れ 上にノイズが確認できる部位にて久落箇所も見られる。

〈5.4〉処理時間 CPU:Pentium4 2.8GHz, OS: LINUX の環境下で, 方向サイズ可変フィルタの処理時間は 18 秒であった。対象画像中の直線状構造物の量によって, フィルタの伸長回数が異なるため, 画像ごとに処理時間の 変動が予想されるが, 実験画像の 2 枚については, ほぼ同 じ時間であった。閯值処理は 1 秒未満となり, 全体の合計 処理時間は, 18 秒であった。下水道の検査では, 夜間に一 区閒の下水道全体の検査完了が求められる。一区間の下水 道から得られる画像枚数は約 2000 枚である。従って, 一枚 
あたり 18 秒の処理時間であれば，10 時間で全ての処理が 完了し，現状でも検査時間の要求は満たすと言える。

\section{2. まとめ}

ひび割れの大局的な方向性に着目し，画素ごとにフィル タの方向とサイズが変化する方向サイズ可変フィルタを適 用した出力に, 統合処理を施すことで, 下水道内面画像か ら，ひび割れ候補画素を検出する手法を提案した。実験結 果から, 提案手法のフィルタ処理によって，ひび割れに対 する背景領域との反応の割合が，従来のフィルタに対し 2 倍近く向上したことが確認された。また, フィルタの出力 である，反応值及びフィルタ方向を統合することで，フィ ルタ出力画像への一律の閾值設定を施した場合よりも，ノ イズを減少させることができた。しかしながら，ひび割れ の一部が, $32 \times 32$ 画素より狭い領域で特に複雑に方向が変 化している場合や，ひび割れのコントラスト低い部位では 背景構造物と誤識別された部分も見られ，これらを改善す るため, より大局的な方向特徵を用いる更なる改良が，今 後の課題として考えられる。

(平成 17 年 2 月 21 日受付，平成 17 年 9 月 15 日再受付)

\section{文献}

(1) T. Yasuda, S. Taniguchi, S. Kamewada, and G. Okano : "Development of a crack evaluation system for superannuated tunnels.", J. of Construction Management and Eng. VI, 435/VI-15, pp.139-144 (1991)

安田 亨・谷口親平・亀和田俊一・岡野吾一:「老朽トンネルにおけ るクラック診断システムの開発」, 土木学論 VI, 435/VI-15, pp.139-144 (1991)

(2) R. Kuroki and H. Yoshikawa : "Crack Diagnosis Expert System by Introducing Fuzzy Measure", Proc. of Annual Conference of the Japan Soc. of Civil Eng., Vol.52, pp.248-249 (1997) 黒木礼則・吉川弘道:「ファジィ測度を用いたひび割れ診断エキスパ ートシステムの構築」, 土木学会年次学術講演会講演概要集共通セッ ション, Vol.52, pp.248-249 (1997)

(3) K. Terada and N. Hatami : "An Automated Crack Analysis Sytem", J. of the Japan Soc. of Civil Eng., Vol.83, No.3, pp.25-26 (1998-3) (in Japanese)

寺田啓治・畠見尚彦：「自動ひび割れ解析システム」, 土木学誌，83, 3, pp.25-26 (1998-3)

（4）脇川武美: “下水道管渠内面展開図化システムの開発”, 第 35 回下水 道研究発表会講演集, pp.312-314 (1998)

（5）興水大和：“直線パターン検出のための HOUGH 曲線追跡型アルゴ リズム”，信学技報，PRL85-2 (1985)

（6）中川雅通・佐藤俊輔：“Hough 変換によるパターン特徴抽出”, 信学 技報, MBE87-139 (1988)

（7）山口友之・橋本周司：「Gray-scale Hough 変換を用いたコンクリー 卜表面のひび割れ検出」, 信学技報, PRMU2004-61（2004-09） pp.57-64 (2004)

(8) H. Okuda and K. Deguchi : "Gray Level Edge Behavior for the Gaussian Blurring Filters and Its Application to Edge Extractions”, ISPJ Trans., Vol.36, No.10, pp.2244-2251 (1995-10) 奥田浩人・出口光一郎 :「ガウシアンフィルタによる濃淡エッジの振 舞いとエッジ抽出」, 情処学論, 36, 10, pp.2244-2251 (1995-10)

(9) S. Mallat and S. Zhong : "Characterization of Signals from Multiscale Edges", IEEE Trans. on PAMI, Vol.14, No.7, pp.710-732 (1992)

(10) I. E. Abdou and W. K. Pratt : "Quantitative Design and Evaluation of Enhancement/Thresholding Edge Detectors", Proc. of the IEEE, Vol.67, No.5, pp.753-763 (1979-5)

(11) L. Kitchen and A. Rosenfeld : "Edge Evaluation Using Local Edge Coherence", IEEE Trans. on SMC, Vol.11, No.9, pp.597-605 (1981-9)

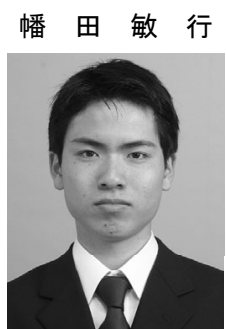

（非会員） 2005 年 3 月岐阜大学卒業。現在, 同大学工学研究科博士前期課程在学中。画像処 理の応用技術に関する研究に従事。

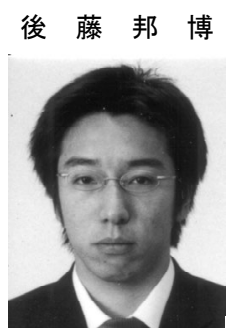

（学生員） 2001 年岐阜大学工学部応用情報 学科卒業。2003 年同大大学院工学研究科博 士前期課程修了。現在, 同大大学院工学研究 科博士後期課程在学中。遺伝的アルゴリズ 么, 画像処理の研究に従事。

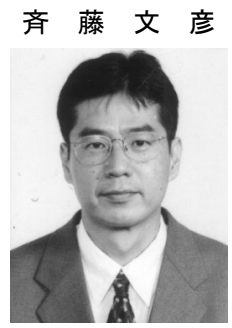

（正員） 1981 年慶応義塾大学工学部数理学科 卒業。日本 IBM(株)等を経て, 現在, 岐皁大学 工学部応用情報学科教授。博士（情報科学、工 学)。マシンビジョン, 視覚情報処理の研究に 従事。精密工学会, 電子情報通信学会, 画像電 子学会等会員。

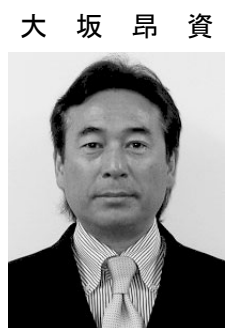

（非会員） 1974 年東京都下水道局入局。2006 年東京都下水道サービス株式会社派遣。現在, 技術部技術開発課課長補佐, 下水道管路内調查 技術開発に従事。

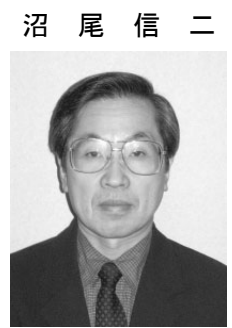

(正員) 1978 年宇都宮大学大学院工学研究科 修了。日本工営株式会社入社, 現在に至る。地 中線・監視制御・画像処理の研究開発に従事。 技術士（電気・電子部門，総合技術監理部門）。

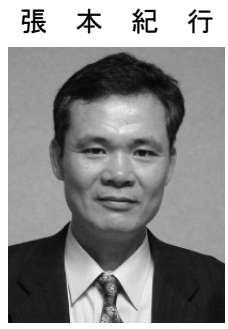

（非会員） 1993 年武蔵工業大学大学院工学研 究科修了。日本工営株式会社入社, 現在に至る。 画像処理・監視制御の研究開発に従事。技術士 (情報工学部門, 総合技術監理部門)。情報処 理学会会員。 